\title{
HUBUNGAN ANTARA KEGIATAN LITERASI DENGAN PRESTASI BELAJAR SISWA DI SMP NEGERI 107 JAKARTA
}

\section{THE RELATION BETWEEN LITERACY ACTIVITIES AND STUDENTS' LEARNING ACHIEVEMENTS AT SMP NEGERI 107 JAKARTA}

\author{
Billy Antoro, Endry Boeriswati, dan Eva Leiliyanti \\ Universitas Negeri Jakarta \\ Jl. Rawamangun Muka No. 11, Rawamangun, Jakarta Timur \\ E-mail: BillyAntoro_9905817009@mhs.unj.ac.id
}

Naskah diterima tanggal: 16-08-2021 disetujui tanggal: 31-10-2021

\begin{abstract}
The School Literacy Movement (Gerakan Literasi Sekolah, GLS) has been implemented for five years and the success of this program needs to be evaluated. This study aims to determine the relationship between literacy activities and students' achievement at SMP Negeri 107 Jakarta. The method used is descriptive with a quantitative approach. The subjects of this study are students of class VIII and class IX consisting of 216 people. Data collection methods used are questionnaires, interviews, observation, and documentation. The results show that literacy activities does not influence students' achievement. In addition, the literacy activities are also less effective because 1) students focus too much on summarizing activities rather than understanding reading, 2) not all of the teachers follow up the literacy activities neither in writing nor verbal, 3) not all students have the ability to apply reading strategies, 4) not all students use reading strategies to understand the text, and 5) there are not many students who use non-lesson sources to enrich their knowledge.
\end{abstract}

Keywords: implementation of GLS, literacy activities, learning achievements, reading strategies

\begin{abstract}
Abstrak: Pelaksanaan Gerakan Literasi Sekolah (GLS) telah bergulir selama lima tahun sehingga program ini perlu dievaluasi keberhasilannya di ranah satuan pendidikan. Penelitian ini bertujuan untuk mengetahui hubungan kegiatan literasi terhadap prestasi belajar siswa di SMP Negeri 107 Jakarta. Metode yang digunakan adalah deskriptif dengan pendekatan kuantitatif. Subjek penelitian ini adalah siswa kelas VIII dan kelas IX berjumlah 216 orang. Metode pengumpulan data yang digunakan adalah penyebaran kuesioner, wawancara, observasi, dan dokumentasi. Hasil penelitian menunjukkan tidak ada pengaruh kegiatan literasi terhadap prestasi belajar siswa SMP Negeri 107 Jakarta. Kegiatan literasi yang telah berjalan juga kurang efektif karena 1) siswa terlalu berfokus pada kegiatan merangkum daripada memahami bacaan, 2) tidak semua guru melakukan kegiatan tindak lanjut berupa tanggapan secara lisan dan tulisan, 3) tidak semua siswa memiliki kemampuan menggunakan strategi membaca, 4) tidak semua siswa menggunakan strategi membaca untuk memahami teks, dan 5) jumlah siswa yang menggunakan sumber nonpelajaran untuk memperkaya pengetahuan dalam mata pelajaran belum terlalu banyak.
\end{abstract}

Kata kunci: implementasi GLS, kegiatan literasi, prestasi belajar, strategi membaca 
Billy Antoro, Endry Boeriswati, \& Eva Leiliyanti, Hubungan antara Kegiatan Literasi dengan Prestasi Belajar Siswa di SMP Negeri 107 Jakarta

\section{PENDAHULUAN}

Beberapa tahun terakhir, perkembangan kompetensi literasi siswa Indonesia menjadi perhatian publik. Survei sejumlah lembaga internasional menunjukkan rendahnya posisi literasi siswa Indonesia dibandingkan dengan negara lain. Di antara survei yang ada, hasil Programme for International Student Assessment (PISA) menjadi acuan pemerintah Indonesia dalam pengambilan kebijakan di dunia pendidikan saat ini.

Pada survei PISA 2000-2018, peringkat literasi siswa Indonesia menurun. Pada PISA 2015, Indonesia berada di peringkat ke-64 dari 72 negara yang disurvei (OECD, 2016). Tiga tahun kemudian, 2018, angka ini merosot menjadi peringkat ke-74 dari 79 negara (OECD, 2019). Penurunan skor yang paling tajam terjadi pada literasi membaca, yaitu 26 poin. Skor literasi membaca pada PISA 2018 dan 2000 sama, yaitu 371. Ini artinya selama 18 tahun, kompetensi literasi membaca siswa Indonesia tidak mengalami perkembangan.

Untuk mengentaskan rendahnya kompetensi literasi siswa, pada 2015 Kementerian Pendidikan dan Kebudayaan RI menerbitkan Peraturan Menteri Pendidikan dan Kebudayaan Nomor 23 Tahun 2015 tentang Penumbuhan Budi Pekerti. Permendikbud ini menjadi dasar munculnya program Gerakan Literasi Sekolah (Antoro, 2018). Sasaran program ini adalah semua warga sekolah di jenjang pendidikan dasar dan pendidikan menengah se-Indonesia (Kementerian Pendidikan dan Kebudayaan, 2019a). Tujuan program ini yaitu menjadikan satuan pendidikan sebagai organisasi pembelajaran yang memiliki budaya literasi dan menjadikan warga sekolah sebagai orang-orang yang literat dalam baca-tulis, numerasi, digital, sains, finansial, budaya, dan kewargaan (Kementerian Pendidikan dan Kebudayaan, 2019a).

Untuk memotret kompetensi literasi siswa Indonesia, beberapa unit kerja di lingkungan
Kemendikbud melakukan survei. Pada 2016, Pusat Penilaian Pendidikan, Badan Penelitian dan Pengembangan Kemendikbud mengadakan Indonesia National Assessment Programme (INAP) kepada siswa kelas IV SD se-Indonesia. Hasilnya menunjukkan (Kementerian Pendidikan dan Kebudayaan, 2016b) literasi matematika siswa Indonesia berada pada kategori kurang (77,13\%), cukup $(20,58 \%)$, dan baik $(2,29 \%)$. Literasi membaca siswa Indonesia berada pada kategori kurang $(46,83 \%)$, cukup $(47,11 \%)$, dan baik $(6,06 \%)$. Literasi sains siswa Indonesia berada pada ketegori kurang $(73,61 \%)$, cukup $(25,38 \%)$, dan baik $(1,01 \%)$. Dari capaian tersebut dapat disimpulkan bahwa literasi matematika, membaca, dan sains siswa Indonesia berada pada kategori belum tergolong tinggi.

Badan Pengembangan dan Pembinaan Bahasa pada 2018 mengadakan survei dengan responden siswa SMA se-Indonesia. Kajian ini menyebutkan rerata skor literasi membaca siswa secara nasional yaitu 489 atau berada pada level 3 (Kementerian Pendidikan dan Kebudayaan, 2018). Kemudian, Pusat Penelitian Kebijakan, Balitbang Kemendikbud, pada 2019 mengadakan survei indeks Aktivitas Literasi Membaca. Melalui survei ini diketahui bahwa rerata Indeks Alibaca Nasional masuk dalam kategori aktivitas literasi rendah dengan skor 37,32 (Kementerian Pendidikan dan Kebudayaan, 2019c).

Kehadiran program Gerakan Literasi Sekolah (GLS) di tengah penurunan skor PISA, INAP, dan survei literasi skala nasional lainnya menimbulkan pertanyaan pada efektivitas penyelenggaraan GLS di sekolah. Sejumlah penelitian telah dilakukan untuk mendalami efektivitas pelaksanaan GLS.

Penelitian Mayuni, Leiliyanti, Agustina, Yulianti, Chen, \& Chu (2020) menyebutkan bahwa gerakan literasi di Indonesia berfokus pada pengembangan karakter sebagai fondasi GLS, sementara Taiwan yang meluncurkan 
literasi multibahasa pada 2008 berfokus pada pembelajaran multibahasa untuk mengembangkan kebiasaan membaca sejak lahir. Perbedaan esensial keduanya terletak pada peran guru. Di Indonesia, guru menugaskan siswa untuk merangkum hasil bacaan setelah membaca, sementara guru Taiwan mendorong siswa untuk memberi umpan balik secara tertulis pada bahan bacaan.

Penelitian Murti dan Winoto (2018), menemukan hubungan signifikan antara kemampuan literasi siswa dan prestasi belajar siswa. Variabel literasi informasi yang digunakan adalah kemampuan merumuskan masalah, kemampuan melakukan pencarian informasi, kemampuan menentukan lokasi dan akses informasi, kemampuan menggunakan informasi, kemampuan melakukan sintesis, serta melakukan evaluasi terhadap sumber informasi; sementara data prestasi belajar siswa dilihat dari rapor siswa.

Penelitian Giovanni dan Komariah (2019) menyimpulkan bahwa penguasaan literasi digital memiliki hubungan yang signifikan dengan prestasi belajar siswa. Variabel literasi digital yang digunakan adalah kompetensi informasi, kompetensi komunikasi, kompetensi kreasi konten, dan kompetensi keamanan; sedangkan prestasi belajar dilihat dari rangking, nilai, dan motivasi belajar siswa.

Penelitian Hendrika dan Zainuddin (2020) menemukan bahwa terdapat pengaruh signifikan antara program literasi terhadap prestasi belajar siswa. Variabel program literasi yang digunakan adalah frekuensi siswa dalam menjalankan program 15 menit membaca buku nonpelajaran, sedangkan prestasi belajar siswa dilihat dari nilai rapornya.

Dari penelitian Murti dan Winoto (2018), Giovanni dan Komariah (2019), serta Hendrika dan Zainuddin (2020), dapat disimpulkan bahwa penelitian mengenai efektivitas pelaksanaan program literasi di sekolah selalu dikaitkan antara pengaruh program atau kemampuan literasi dengan prestasi belajar siswa. Ketiga artikel tersebut menunjukkan adanya korelasi yang signifikan di antara kedua variabel tersebut. Semakin baik kemampuan literasi siswa, prestasi belajar siswa pun semakin meningkat.

Berbeda dengan penelitian yang sudah dilakukan, penelitian ini hendak mengetahui hubungan kegiatan literasi terhadap prestasi belajar siswa dengan kegiatan literasi dari indikator ketercapaian implementasi GLS pada kegiatan pembiasaan, pengembangan, dan pembelajaran (Kementerian Pendidikan dan Kebudayaan, 2019b). Kegiatan yang dilakukan yaitu menulis rangkuman pada jurnal membaca, tindak lanjut 15 menit membaca berupa kegiatan tanggapan secara lisan dan tulisan, penggunaan strategi membaca dalam kegiatan pembelajaran, penggunaan strategi membaca dalam memahami teks, dan penggunaan sumber bacaan nonpelajaran untuk memperkaya materi pelajaran. Prestasi belajar siswa menggunakan rapor siswa tahun ajaran 2020/2021 semester 1.

Penelitian ini dilakukan di SMP Negeri 107 Jakarta karena sekolah ini telah menjalankan program GLS dan merupakan Sekolah Standar Nasional. Berdasarkan uraian di atas, rumusan masalah penelitian ini adalah bagaimana hubungan antara kegiatan literasi dengan prestasi belajar siswa di SMP Negeri 107 Jakarta. Sebagai triangulasi, peneliti mewawancarai siswa dan guru.

\section{METODE}

Penelitian ini menggunakan pendekatan kuantitatif. Subjek penelitian adalah siswa-siswi SMP Negeri 107 Jakarta. Responden survei diambil dengan teknik pemilihan sampel secara acak (random sampling), yaitu siswa kelas VIII dan IX berjumlah 216 siswa. Siswa kelas VIII dan kelas IX dipilih karena pertanyaan yang diajukan yaitu seputar implementasi GLS sebelum masa pandemi COVID-19. Siswa kelas VII tidak dipilih sebagai responden karena belum melaksanakan implementasi GLS sejak awal 
Billy Antoro, Endry Boeriswati, \& Eva Leiliyanti, Hubungan antara Kegiatan Literasi dengan Prestasi Belajar Siswa di SMP Negeri 107 Jakarta

tahun ajaran baru 2020/2021. Data dikumpulkan melalui penyebaran kuesioner dengan Google Form pada November 2020 dan wawancara melalui sambungan telepon pada awal Januari 2021.

Siswa mengisi kuesioner dengan pertanyaan berjumlah 20 butir. Pertanyaan-pertanyaan itu merupakan indikator ketercapaian implementasi GLS pada kegiatan pembiasaan, pengembangan, dan pembelajaran yang sudah disederhanakan. Pertanyaan-pertanyaan tersebut berisi tentang kegiatan literasi yang dilakukan oleh siswa, program literasi yang diadakan oleh sekolah, dan fasilitas literasi. Dari ketiga kategori pertanyaan, pertanyaan kegiatan literasi dianalisis.

Kegiatan literasi yang dilakukan oleh siswa terdiri dari lima butir. Satu butir pada kegiatan pembiasaan, yaitu menulis rangkuman pada jurnal membaca; satu butir pada kegiatan pengembangan, yaitu tindak lanjut kegiatan 15 menit membaca melalui tanggapan secara lisan dan tulisan; dan tiga butir pada kegiatan pembelajaran, yaitu menggunakan strategi membaca dalam kegiatan pembelajaran, menggunakan strategi membaca dalam memahami teks, dan menggunakan sumber bacaan nonpelajaran untuk memperkaya materi pelajaran (Tabel 1).

Data kuesioner yang berupa jawaban atas lima pertanyaan tersebut kemudian disandingkan dengan rapor siswa tahun ajaran 2020/2021 semester 1 yang didapat dari Data Pokok Pendidikan (Dapodik) Kemendikbudristek. Hubungan kedua variabel kemudian diukur dengan uji korelasi.

\section{HASIL DAN PEMBAHASAN}

Untuk membangun budaya literasi di sekolah, Beers, Beers, \& Smith (2009) menyarankan agar sekolah menciptakan lingkungan fisik ramah literasi, membangun lingkungan sosial dan afeksi yang ramah literasi, dan membangun lingkungan akademik yang ramah literasi. Dalam GLS, ketiga strategi tersebut dijalankan sesuai dengan kondisi sekolah dan siswa melalui tiga fase implementasi. Ketiga fase implementasi itu yakni pembiasaan, pengembangan, dan pembelajaran.

Panduan GLS di SMP (Kementerian Pendidikan dan Kebudayaan, 2019b) telah menetapkan indikator ketercapaian pada tiap fase implementasi. Penelitian ini menggunakan indikator-indikator tersebut sebagai instrumen pertanyaan dalam kuesioner. Berdasarkan kondisi di lapangan, peneliti telah merangkum indikatorindikator tersebut menjadi 20 pertanyaan yang ditujukan kepada siswa. Daftar pertanyaan telah divalidasi oleh pakar literasi Sofie Dewayani.

\section{Implementasi GLS pada Kegiatan Pembiasaan}

Permendikbud Nomor 23 Tahun 2015 tentang Penumbuhan Budi Pekerti mewajibkan sekolah menjalankan kegiatan membaca buku nonpelajaran selama 15 menit sebelum jam pembelajaran dimulai setiap hari. Di SMP Negeri 107 Jakarta, program ini berjalan sejak awal 2019.

Dari sepuluh pertanyaan dalam kegiatan pembiasaan, diketahui mayoritas siswa mengetahui dan menjalankan program 15 menit membaca sebanyak 4-5 kali dalam seminggu

Tabel 1 Kegiatan Literasi pada Indikator Ketercapaian Implementasi GLS

\begin{tabular}{|c|c|}
\hline Fase Implementasi & Kegiatan Literasi \\
\hline Pembiasaan & Menulis rangkuman pada jurnal membaca \\
\hline Pengembangan & $\begin{array}{l}\text { Tindak lanjut kegiatan membaca berupa menulis rangkuman di jurnal } \\
\text { membaca dan menceritakan kembali hasil bacaan }\end{array}$ \\
\hline Pembelajaran & $\begin{array}{l}\text { Menggunakan strategi membaca dalam kegiatan pembelajaran } \\
\text { Menggunakan strategi membaca dalam memahami teks } \\
\text { Menggunakan sumber bacaan nonpelajaran untuk memperkaya } \\
\text { materi pelajaran }\end{array}$ \\
\hline
\end{tabular}


(78\%) dan $13 \%$ siswa mengatakan tiga kali dalam seminggu. Program 15 menit membaca dilaksanakan tiap Selasa, Rabu, dan Kamis. Siswa masuk kelas pukul 06.30 WIB, dimulai dengan membaca kitab suci pukul 06.30-06.45 WIB, dilanjutkan dengan membaca buku nonpelajaran pukul 06.45-07.00 WIB. Khusus pada Jumat, kegiatan literasi digelar setiap minggu ke-4. Pada Jumat ke-4 pukul 07.30 WIB, seluruh siswa berkumpul di lapangan upacara dan membaca buku. Guru-guru juga berada di sekitar siswa. Mereka ada yang ikut membaca dan mengawasi. Selain membaca, siswa diminta untuk menceritakan hasil bacaannya setelah melalui proses undian. Siswa yang ingin membaca karya juga dipersilahkan menyampaikan di depan siswa.

Usai membaca buku nonpelajaran, siswa merangkum hasil bacaan di buku tulis yang dinamakan jurnal membaca. Mayoritas siswa (94\%) memiliki jurnal membaca. Pada jurnal membaca, siswa mencatat judul buku, pengarang, halaman yang dibaca, dan resume.

Saat siswa membaca buku nonpelajaran, guru juga membaca (67\%) bersama siswa. Sebanyak $24 \%$ siswa mengatakan guru, kepala sekolah, dan tenaga kependidikan ikut membaca, sedangkan 33\% siswa mengatakan sebaliknya (tidak ikut membaca). Guru tidak ikut membaca dan mendiskusikan isi buku sangat disayangkan karena jika dilakukan kegiatan tersebut akan membuat siswa selalu bersemangat dalam aktivitas membaca (Pilgreen, 2000).

Sekolah memiliki perpustakaan dengan koleksi sebanyak 2.000-an judul buku nonpelajaran (nonfiksi, fiksi, filsafat, dan agama) dan 1.700-an buku teks pelajaran (buku paket). Sebanyak $42 \%$ responden siswa mengatakan bahwa perpustakaan sekolah memiliki koleksi buku nonpelajaran yang memadai dan ada kegiatan literasi rutin (diskusi, bedah buku, dll). Sebanyak $37 \%$ responden siswa mengatakan kondisi perpustakaan sekolah cukup baik.
Sedangkan $12 \%$ responden siswa menyatakan perpustakaan didominasi dengan buku pelajaran dan hanya $9 \%$ yang menyatakan perpustakaan menyimpan koleksi buku nonpelajaran memadai.

Dari wawancara dengan tenaga perpustakaan, perpustakaan tidak memiliki program literasi seperti peluncuran buku dan pelatihan meresensi. Perpustakaan hanya menjalankan fungsi administratif yaitu peminjaman dan pengembalian buku. Kurangnya waktu siswa untuk berkunjung ke perpustakaan karena bersamaan dengan waktu istirahat. "Saya juga bingung. Anak waktunya susah. Mereka butuh istirahat," kata tenaga perpustakaan.

Program GLS dan fasilitas perpustakaan berpengaruh positif terhadap minat baca siswa (Mokoagow, Pongoh, \& Watung, 2021; Afifah, Erwina, \& Rohman, 2020). Dalam implementasi GLS, pustakawan memiliki peran sangat penting (Srirahayu, Kusumaningtiyas, \& Harisanty, 2021) yang diharapkan mendukung pembelajaran literasi siswa (Merga, 2020).

Tiap kelas memiliki sudut baca. Sudut baca berisi koleksi buku nonpelajaran yang bervariasi (31\%), bervariasi dan disukai siswa (56\%), sedangkan $10 \%$ responden menyatakan sedikit koleksi buku nonpelajaran. Keberadaan sudut baca di tiap kelas dapat meningkatkan minat baca siswa (Ramandanu, 2019). "Saya sering juga membaca buku dan berdiskusi dengan teman-teman," kata seorang siswa.

Mayoritas responden siswa menyatakan poster kampanye membaca terlihat di sejumlah tempat di lingkungan sekolah. Sebanyak 50\% responden melihat poster kampanye membaca di kelas, koridor, dan area lain di sekolah, dan sebanyak $29 \%$ responden melihatnya di kelas dan koridor sekolah. Sebanyak $14 \%$ responden melihat poster kampanye membaca di kelas yang menarik dan hanya 3\% responden menilai poster kampanye membaca di kelas tidak menarik.

Mayoritas responden siswa juga melihat bahan kaya ragam teks di lingkungan sekolah (kelas). Sebanyak 59\% responden menyebutkan 
bahan kaya ragam teks sudah ada di tiap kelas dan menarik. Sebanyak $28 \%$ responden menyatakan bahan kaya ragam teks ada di beberapa kelas dan menarik. Sebanyak $8 \%$ responden menyampaikan ada bahan kaya ragam teks di setiap kelas tetapi kurang menarik, dan hanya $2 \%$ responden mengungkapkan bahwa bahan kaya ragam teks ada di beberapa kelas dan kurang menarik.

Mayoritas responden juga menyebutkan melihat poster tentang pembiasaan hidup bersih, sehat, dan indah terpampang di sekitar sekolah. Sebanyak $79 \%$ responden siswa melihat poster tentang pembiasaan hidup bersih, sehat, dan indah di kebun, kantin, dan UKS menarik. Sebanyak $11 \%$ responden melihat poster tentang pembiasaan hidup bersih, sehat, dan indah di kebun dan kantin sekolah. Sebanyak $6 \%$ responden melihat poster tentang pembiasaan hidup bersih, sehat, dan indah di kebun, kantin, dan UKS tetapi kurang menarik. Sebanyak $4 \%$ responden melihat poster pembiasaan hidup bersih, sehat, dan indah di kebun sekolah.

Mengenai pelibatan pihak eksternal dalam program literasi, menurut kepala sekolah masih dalam perencanaan. "Guru bahasa Indonesia ingin mendatangkan Rumah Seni Asnur Depok. Kami sudah menghubungi untuk mengajarkan sastra kepada siswa, membacakan, dan mencipta puisi," kata Kepala Sekolah.

Hasil kuesioner menunjukkan 46\% responden siswa melihat sekolah hanya melibatkan orang tua dan komite sekolah dalam pengembangan kegiatan literasi di sekolah. Selebihnya, responden bervariasi dalam menilai pelibatan unsur eksternal. Sebanyak 23\% responden menilai sekolah tidak melibatkan orang tua, alumni, atau masyarakat dalam pengembangan kegiatan literasi sekolah. Sebanyak $21 \%$ menyebutkan sekolah selalu melibatkan orang tua, alumni, atau masyarakat dalam pengembangan kegiatan literasi sekolah. Sebanyak $10 \%$ responden menyatakan sekolah melibatkan orang tua, alumni, atau masyarakat dalam pengembangan kegiatan literasi sekolah tetapi sesekali saja.

Telah menjadi hal umum bahwa kegiatan literasi sekolah di Jakarta hanya berfokus pada kegiatan di dalam sekolah, tidak melibatkan pihak eksternal (Mayuni, Leiliyanti, Agustina, \& Antoro, 2020). Padahal, pelibatan publik antara lain orang tua, masyarakat sekitar sekolah, dan pemangku kepentingan lainnya berpengaruh pada tumbuhnya minat membaca siswa (Ramandanu, 2019).

Untuk menciptakan ekosistem yang literat perlu dibentuk tim literasi sekolah atau pokja literasi yang bertugas merencanakan, melaksanakan, melaporkan, dan melakukan asesmen serta mengevaluasi pelaksanaan GLS (Kementerian Pendidikan dan Kebudayaan, 2016a). SMP Negeri 107 Jakarta telah memiliki pokja literasi tetapi keberadaannya belum diketahui oleh semua siswa. Hasil kuesioner menunjukkan $24 \%$ responden siswa tidak mengetahui adanya pokja literasi. Di sisi lain, mayoritas siswa yang mengetahui keberadaan pokja literasi memiliki penilaian berbeda tentang peran pokja. Sebanyak $51 \%$ responden, misalnya, memandang siswa dilibatkan dalam kepengurusan pokja dan kegiatannya berjalan baik. Sebanyak $11 \%$ responden menyatakan pokja tidak melibatkan siswa dalam kepengurusannya. Sebanyak $7 \%$ responden menyampaikan pokja melibatkan siswa dalam kepengurusannya tetapi tidak berjalan baik. Sedangkan $6 \%$ responden menilai pokja belum berjalan sesuai harapan.

Untuk Kegiatan Pembiasaan, pertanyaan kuesioner berada nomor 1-10. Dari 10 indikator ketercapaian kegiatan pembiasaan, kegiatan literasi yang dilakukan langsung oleh siswa adalah aktivitas mencatat rangkuman hasil bacaan pada jurnal membaca. Sebanyak $94 \%$ responden siswa menyatakan memiliki jurnal membaca yang digunakan untuk mencatat judul buku, pengarang, halaman yang dibaca, dan 
rangkuman.

Aktivitas merangkum banyak membawa dampak positif. Kegiatan ini terbukti dapat mendorong nalar anak agar dapat berkembang luas (Suyanto, 2021). Kegiatan ini juga berkorelasi positif dan signifikan dengan kecerdasan linguistik (Dwiprabowo, 2021).

Berdasarkan data kuesioner yang diberikan kepada guru, 90\% guru menyatakan bahwa telah mengajarkan strategi merangkum yang benar kepada siswa. Namun, dari wawancara dengan siswa, diketahui bahwa yang mengajarkan cara merangkum yang benar hanya guru bahasa Indonesia. "Pagi ada kegiatan literasi, kami ditugaskan meringkas. Kami diingatkan agar meringkasnya menggunakan kata-kata sendiri. Setelah menulis di buku literasi lalu diparaf. Jika ada kosakata yang salah, dibenarkan. Kalau textbook, kami diminta menggunakan kata-kata sendiri," kata seorang siswa.

Dalam kegiatan 15 menit membaca buku nonpelajaran, siswa tidak diperkenankan untuk meneruskan aktivitas membaca buku yang sama, misalnya saat jam istirahat atau di rumah. "Satu setengah lembar saja, sih. Besok dilanjutkan ," kata seorang siswa tentang jumlah halaman yang dibaca dalam 15 menit. Hal ini dapat mengurangi minat dan keasyikan siswa dalam membaca karena aktivitasnya terpotong sekian lama.

Hal lain terkait aktivitas merangkum adalah fenomena siswa lebih fokus merangkum daripada membaca. Mereka membaca dengan tujuan memindahkan teks menjadi rangkuman tanpa berupaya menikmati dan memahami bahan bacaan. Hal ini disampaikan oleh seorang siswa yang prihatin kepada teman-temannya. "Biasanya kendalanya kita hanya fokus pada meringkas, tidak fokus pada membaca," ucapnya.

Dari beberapa peristiwa di atas, dapat disimpulkan bahwa aktivitas merangkum bahan bacaan di kalangan siswa belum berjalan baik. Aktivitas merangkum dipandang sebagai kegiatan ritual setelah membaca tanpa berupaya memahami bahan bacaan.

\section{Implementasi GLS pada Kegiatan Pengembangan}

Usai kegiatan membaca buku nonpelajaran selama 15 menit, siswa umumnya ditugaskan membuat rangkuman hasil bacaan. Ironinya, mayoritas responden siswa (53\%) menyatakan tidak ada kegiatan tersebut. $43 \%$ responden mengaku tidak ada kegiatan tersebut dan $10 \%$ menyatakan tidak ada tindak lanjut. Lainnya, $29 \%$ responden menyatakan ada kegiatan dalam bentuk lisan dan tulisan. Sebanyak 12\% responden menyatakan ada tindak lanjut tetapi sesekali saja, dan $6 \%$ menyatakan tindak lanjut menghasilkan tanggapan secara lisan. Yang dimaksud dengan tanggapan secara lisan yaitu menceritakan hasil bacaan ke depan kelas.

Mengenai peletakan Jurnal Tanggapan Membaca dan Hasil Prestasi Siswa di kelas dan/ atau koridor sekolah, 39\% siswa menyatakan tidak ada hal seperti itu. Sebanyak 22\% menyatakan dipajang di kelas. 20\% menyatakan selalu dipajang di kelas dan/atau koridor sekolah. $10 \%$ menyatakan kadang-kadang dipajang di kelas dan/atau koridor sekolah, dan 9\% menyatakan dipajang di koridor sekolah. Sedangkan $65 \%$ guru menyatakan kedua hal tersebut dilakukan dan sisanya 35\% menyatakan tidak. Dalam amatan peneliti, yang dipajang di kelas dan/atau koridor sekolah adalah pohon literasi. Pohon literasi adalah kertas karton yang dibentuk menjadi pohon dan daun-daunnya ditulisi judul serta identitas buku yang sudah selesai dibaca siswa.

Sebanyak $42 \%$ responden siswa menyatakan tidak ada pemberian penghargaan oleh pihak sekolah terhadap pencapaian siswa di bidang literasi. Sebanyak 27\% mengatakan penghargaan diberikan secara berkala, $21 \%$ menyatakan penghargaan kadang-kadang diberikan, $6 \%$ responden menyebutkan penghargaan diberikan satu kali dalam satu semester, 
Billy Antoro, Endry Boeriswati, \& Eva Leiliyanti, Hubungan antara Kegiatan Literasi dengan Prestasi Belajar Siswa di SMP Negeri 107 Jakarta

dan $4 \%$ responden mengatakan penghargaan diberikan satu kali dalam satu tahun.

Kegiatan akademik yang mendukung budaya literasi sekolah sangat penting. Misalnya, wisata ke perpustakaan dan kunjungan perpustakaan keliling ke sekolah. Namun, $42 \%$ responden siswa menyatakan tidak ada kegiatan seperti itu. Sebanyak $25 \%$ responden mengatakan kegiatan tersebut diadakan secara berkala. Sebanyak $22 \%$ responden menyatakan kegiatan itu dilakukan kadang-kadang, 6\% responden menyebutkan kegiatan itu dilakukan satu kali dalam satu tahun dan $6 \%$ responden mengatakan kegiatan itu dilakukan satu kali dalam satu semester.

Berbeda dengan program sebelumnya, perayaan hari nasional tertentu, menurut $50 \%$ responden siswa, dilaksanakan secara berkala. Sebanyak 29\% siswa menyatakan kegiatan itu kadang-kadang dilaksanakan, 9\% menyatakan tidak ada kegiatan itu, $8 \%$ responden menyebutkan kegiatan itu dilakukan satu kali dalam satu semester, dan $5 \%$ responden menyatakan kegiatan itu dilaksanakan satu kali dalam satu tahun. Menurut Ketua Pokja Literasi, perayaan hari tertentu dengan tema literasi dapat berbentuk lomba misalnya lomba poster, baca puisi, dan cerpen.

Hal lain yang juga penting yaitu kegiatan ekstrakurikuler yang mendukung pengembangan literasi. Sebanyak 39\% siswa menyatakan sekolah menyediakan kegiatan ekstrakurikuler tetapi tidak ada yang terkait dengan pengembangan literasi. Sebanyak 23\% siswa juga menyatakan sekolah tidak menyediakan kegiatan ekstrakurikuler. Di sisi lain, 20\% siswa menyatakan sekolah menyediakan kegiatan ekstrakurikuler untuk pengembangan literasi dan sudah berjalan optimal, $13 \%$ menyatakan sekolah menyediakan tetapi belum berjalan maksimal, dan 5\% menyatakan kegiatan ekstrakurikuler dan pengembangan literasi ada tetapi tidak menarik.
Untuk kegiatan Pengembangan, pertanyaan pada kuesioner berada pada nomor 11-16. Dari enam indikator ketercapaian pada kegiatan pengembangan, kegiatan literasi yang dilakukan langsung oleh siswa adalah tindak lanjut usai kegiatan 15 menit membaca dalam bentuk hasil tanggapan secara lisan dan tulisan. Tanggapan secara lisan yaitu guru meminta siswa untuk maju ke depan kelas dan menceritakan hasil bacaannya. Sedangkan tanggapan secara tulisan yaitu guru menugaskan siswa membuat rangkuman.

Namun, tidak semua guru melakukan tindak lanjut kegiatan berupa tanggapan secara lisan dan tulisan. Berdasarkan hasil kuesioner, hanya $71 \%$ guru yang menyatakan melakukannya dan 29\% guru mengatakan tidak melakukan.

Alokasi waktu bagi siswa untuk bercerita di depan kelas pun tidak banyak. Hanya beberapa siswa yang diminta menceritakan hasil bacaannya karena waktunya terbatas.

\section{Implementasi GLS pada Kegiatan Pembelajaran}

Siswa dapat dengan mudah memahami teks yang dibacanya jika menerapkan strategi membaca yang benar (Sari, Astuti, Lubis, \& Hutagalung, 2020; Handayani, Sepyanda, Dwiputri, \& Zulfariati, 2020; Rayantie, Hartati, \& Rengganis, 2019). Mereka juga dapat berpikir sistematis sesuai langkah-langkah metode yang digunakan (Kemala, Matin, \& Supriyati, 2021). Sebanyak $45 \%$ responden siswa menyatakan mampu menggunakan beberapa strategi membaca secara bervariasi. Sebanyak $17 \%$ siswa mengaku kadang-kadang menggunakan strategi membaca dan 13\% mengatakan jarang menggunakan strategi membaca. Sebanyak 2\% menyebutkan belum mampu menggunakan strategi membaca. Sebaliknya, 25\% siswa tidak menggunakan strategi membaca.

Secara kuantitatif, 40\% siswa menyatakan mampu menggunakan strategi membaca untuk memahami teks dalam semua mata pelajaran. 
Sebanyak 25\% siswa menyatakan menggunakan berbagai strategi untuk memahami teks dalam beberapa mata pelajaran.

Dari sisi guru, 77\% guru pernah mengajarkan strategi membaca kepada siswa. Berdasarkan wawancara, rata-rata responden guru tidak langsung menjawab sudah pernah mengajarkan strategi membaca. "Saya terapkan saat pembelajaran. Sebagai contoh, ada pembelajaran teks deskripsi. Dalam hal ini, saya mengajarkan siswa menulis teks. Caranya disisipkan pada pembelajaran sehari-hari," kata seorang guru.

Siswa menulis rangkuman hasil bacaannya di buku tulis khusus. Sebanyak $27 \%$ responden menyatakan memilikinya dan berisi rangkuman satu buku nonpelajaran, $15 \%$ siswa menyatakan jurnal membacanya berisi minimal 12 buku nonpelajaran, $11 \%$ siswa menyatakan mempunyai jurnal membaca kurang dari enam buku nonpelajaran, dan $13 \%$ siswa menyatakan kumpulan jurnal membacanya berisi buku pelajaran.

Ada 34\% siswa yang menyatakan tidak memiliki buku kumpulan jurnal membaca. Kegiatan merangkum terbukti dapat mendorong nalar anak agar dapat berkembang luas (Suyanto, 2021). Kegiatan ini juga berkorelasi positif dan signifikan dengan kecerdasan linguistik (Dwiprabowo, 2021).

Buku bacaan nonpelajaran menjadi salah satu sumber belajar siswa. Sebanyak 58\% siswa memanfaatkannya untuk memperkaya pengetahuan dalam mata pelajaran, $15 \%$ siswa memanfaatkan hanya beberapa, $14 \%$ siswa menyatakan jarang memanfaatkannya, dan $12 \%$ siswa menyatakan kadang-kadang memanfaatkannya.

Untuk Kegiatan Pembelajaran, pertanyaan kuesioner berada pada nomor 17-20. Dari empat indikator ketercapaian pada kegiatan pembelajaran, kegiatan literasi yang dilakukan langsung oleh siswa adalah menggunakan strategi membaca dalam kegiatan pembelajaran, menggunakan strategi membaca dalam memahami teks, dan menggunakan sumber bacaan nonpelajaran untuk memperkaya materi pelajaran.

Dari ketiga indikator tersebut, kondisi di SMP Negeri 107 Jakarta menunjukkan hal yang tidak ideal. Pertama, terkait penggunaan strategi membaca dalam kegiatan pembelajaran. Membaca tidak sekadar membutuhkan kemampuan mengeja kata. Kegiatan membaca membutuhkan kemampuan menganalisis dan menyintesis informasi (Abidin, Mulyati, \& Yunansah, 2017). Oleh karena itu, siswa perlu diajarkan strategi membaca. Namun, hanya $77 \%$ guru yang pernah mengajarkan siswa strategi membaca. Dari hasil wawancara, diketahui bahwa yang mengajarkan strategi membaca hanya guru bahasa Indonesia. Dari hasil kuesioner, hanya $45 \%$ siswa yang menyatakan menggunakan strategi membaca secara bervariasi. Sedangkan $25 \%$ siswa tidak menggunakan strategi membaca dalam kegiatan pembelajaran.

Kedua, terkait dengan penggunaan strategi membaca untuk memahami teks dalam semua mata pelajaran. Berdasarkan hasil kuesioner, $23 \%$ siswa tidak menggunakan strategi dalam memahami teks.

Ketiga, mengenai pemanfaatan sumber bacaan nonpelajaran untuk memperkaya materi pembelajaran. Hasil kuesioner menunjukkan 58\% responden siswa melakukannya. Dari hasil wawancara diketahui bahwa siswa lebih sering memanfaatkan bahan bacaan nonpelajaran yang ada di sudut baca kelas daripada perpustakaan. Hal ini disebabkan sudut baca berada di dalam kelas dan bisa diakses kapan saja. Sedangkan waktu kunjungan ke perpustakaan dibatasi oleh waktu istirahat yang pendek dan adanya kegiatan ibadah. "Saya jarang sekali ke perpustakaan karena waktu istirahat tidak lama. Kita memanfaatkan waktu untuk makan dan istirahat. Kadang waktu istirahat kita gunakan untuk menyiapkan pelajaran berikutnya," ungkap seorang siswa. 
Billy Antoro, Endry Boeriswati, \& Eva Leiliyanti, Hubungan antara Kegiatan Literasi dengan Prestasi Belajar Siswa di SMP Negeri 107 Jakarta

Keberadaan sudut baca di setiap kelas memang dapat meningkatkan minat baca siswa (Ramandanu, 2019). Namun, kurangnya pemanfaatan fasilitas perpustakaan yang jumlah buku nonpelajarannya lebih banyak daripada di sudut baca sangat disayangkan. Program GLS dan fasilitas perpustakaan berpengaruh positif terhadap minat baca siswa (Mokoagow et al, 2021; Afifah et al, 2020). Dalam implementasi GLS, pustakawan memiliki peran sangat penting (Srirahayu, et al, 2021) yang diharapkan mendukung dalam pembelajaran literasi siswa (Merga, 2020).

\section{Korelasi Kegiatan Literasi dan Prestasi Belajar Siswa}

Uji korelasi antara kegiatan literasi siswa dan rapor siswa dihitung dengan menggunakan Microsoft Excel. Perhitungan itu dapat dilihat pada Tabel 2. Berdasarkan tabel tersebut, skor korelasi antara kegiatan literasi dengan nilai rapor cenderung mendekati nol, artinya hubungannya lemah. Dari perhitungan ini dapat ditarik kesimpulan bahwa tidak ada hubungan antara kegiatan literasi dengan prestasi (nilai rapor) siswa di SMP Negeri 107 Jakarta.

\section{SIMPULAN DAN SARAN}

\section{Simpulan}

Berdasarkan temuan hasil dan pembahasan, kegiatan literasi yang dilakukan sekolah belum efektif. Hal ini diketahui dari rendahnya nilai korelasi antara kegiatan literasi di sekolah dengan nilai rapor siswa. Rerata kegiatan literasi yang dilakukan sekolah hanya mencapai level rendah yang mengindikasikan bahwa kemampuan berliterasi siswa belum tumbuh secara optimal.

Belum optimalnya kemampuan berliterasi siswa SMP Negeri 107 Jakarta dapat dilihat dari kualitas kegiatan literasi yang telah berjalan. Kegiatan merangkum hasil bacaan tidak menunjukkan efektivitasnya. Hal ini disebabkan kegiatan membaca siswa lebih fokus pada merangkum atau memindahkan konten bacaan ke jurnal membaca daripada memahami bahan bacaan. Kegiatan tindak lanjut berupa tanggapan secara lisan dan tulisan juga tidak efektif karena tidak semua guru melakukannya. Selain itu, alokasi waktu bagi siswa untuk menceritakan hasil bacaannya di depan kelas sangat terbatas.

Kemampuan menggunakan strategi membaca tidak dimiliki oleh semua siswa karena tidak semua guru mengajarkannya kepada siswa. Jumlah siswa yang menggunakan strategi membaca untuk memahami teks juga tidak sampai separuhnya. Sementara siswa yang menggunakan sumber bacaan nonpelajaran sedikit lebih banyak dari separuhnya. Mereka memanfaatkan buku di sudut baca kelas yang jumlahnya terbatas daripada buku di perpustakaan yang jumlahnya jauh lebih banyak dari buku di sudut baca.

\section{Saran}

Hubungan antara kegiatan literasi dengan prestasi belajar siswa yang lemah dan tidak signifikan menimbulkan pertanyaan tersendiri. Hal ini mengindikasikan kegiatan literasi yang telah berjalan belum berkontribusi signifikan dalam mendukung prestasi akademik peserta

Tabel 2 Matriks Korelasi

\begin{tabular}{llcc}
\hline & & Kegiatan Literasi & Nilai Rapor \\
\hline \multirow{2}{*}{ Kegiatan Literasi } & Pearson's r & - & 0,016 \\
& p-value & - & 0,851 \\
\multirow{2}{*}{ Nilai Rapor } & Pearson's r & 0,016 & - \\
& p-value & 0,851 & - \\
\hline
\end{tabular}


didik. Oleh karena itu, pada penelitian selanjutnya perlu dicari strategi, bentuk, pola, dan model kegiatan literasi yang lebih efektif untuk menumbuhkan keterampilan literasi siswa. Selain itu, kualitas kegiatan literasi baik yang bersifat akademik maupun nonakademik perlu ditingkatkan.

Peningkatan kualitas kegiatan literasi dapat diawali dengan penyamaan persepsi di antara para pendidik dan tenaga kependidikan mengenai konsep literasi dan menyepakati bentuk kegiatan yang akan dilaksanakan. Guru juga perlu meningkatkan kompetensi literasi dan metode pengajarannya. Kolaborasi dengan pustakawan/tenaga perpustakaan juga perlu dikuatkan dalam bentuk kegiatan yang lebih riil antara lain penggunaan buku nonpelajaran koleksi perpustakaan sebagai referensi bahan ajar.
Kegiatan literasi yang bersifat akademik dan perlu ditingkatkan di antaranya adalah guru mengajarkan strategi membaca dan menekankan siswa agar menggunakannya dalam memahami semua materi pelajaran. Siswa juga perlu didorong untuk memanfaatkan banyak sumber belajar (perpustakaan, internet, dll.) dalam memperkaya materi pelajaran.

Beberapa alternatif kegiatan literasi nonakademik yang dapat dilakukan sekolah di antaranya yaitu kolaborasi dengan pegiat literasi, kunjungan ke perpustakaan daerah, dan mengikutsertakan siswa dalam berbagai lomba literasi. Pemberian penghargaan kepada siswa yang berprestasi di bidang literasi juga dapat dilakukan.

Keterampilan literasi yang penting bagi siswa dapat disesuaikan dengan situasi dan kondisi lingkungan sekolah. Kepala sekolah dan guru juga dapat bertanya kepada siswa tentang keterampilan literasi yang dianggap penting oleh mereka.

\section{PUSTAKA ACUAN}

Abidin, Y., Mulyati, T., \& Yunansah, H. (2017). Pembelajaran literasi: Strategi meningkatkan kemampuan literasi matematika, sains, membaca, dan menulis. Jakarta: Bumi Aksara.

Afifah, N.A., Erwina, W., \& Rohman, A.S. (2020). Peran tenaga perpustakaan dalam mewujudkan keberhasilan Gerakan Literasi Sekolah (GLS) di SD Negeri 02 Rajamandala. 7(2), 105-112. doi.org/10.31849/pb.v7i2.4174

Antoro, B. (2018). Gerakan Literasi Sekolah dari pucuk hingga akar: Sebuah Refleksi (2nd ed.). Jakarta: Kementerian Pendidikan dan Kebudayaan.

Beers, C.S., Beers, J.W., \& Smith, J.O. (2009). A principal's guide to literacy instruction. Guildford Press.

Dwiprabowo, R. (2021). Hubungan kecerdasan linguistik dengan keterampilan menulis ringkasan siswa Kelas III SD Negeri Se-Kelurahan Cipete Utara Jakarta Selatan. Jurnal IImu Pendidikan (JIP) STKIP Kusuma Negara, 12(2), 182-192. doi.org/10.37640/jip.v12i2.861

Giovanni, F., \& Komariah, N. (2019). Hubungan antara literasi digital dengan prestasi belajar siswa SMA Negeri 6 Kota Bogor. LIBRARIA: Jurnal Perpustakaan, 7(1), 147-162. doi.org/ 10.21043/libraria.v7i1.5827

Handayani, F., Sepyanda, M., Dwiputri, R., \& Zulfariati. (2020). Pelatihan penggunaan strategi membaca bagi siswa Kelas IX SMP Negeri 4 Kota Solok Tahun Akademik 2019/2020 dalam menjawab soal ujian nasional bahasa Inggris. Jurnal Puan Indonesia 2(1), 19-32. doi.org/ 10.37296/jpi.v2i1.16 
Billy Antoro, Endry Boeriswati, \& Eva Leiliyanti, Hubungan antara Kegiatan Literasi dengan Prestasi Belajar Siswa di SMP Negeri 107 Jakarta

Hendrika, I., \& Zainuddin, H. (2020). Pengaruh program literasi terhadap prestasi belajar siswa Kelas III SDN 244 Inpres Bera Kabupaten Tana Toraja. Jurnal KIP, IX(3), 31-37. http:// journals.ukitoraja.ac.id/index.php/jkip/article/view/1161

Kemala, R., Matin, \& Supriyati, Y. (2021). Increasing ability to read understanding through PQ4R Method in class IV students SDI Arrayaahiin Bekasi District. Bahtera: Jurnal Pendidikan Bahasa Dan Sastra, 20(1), 84-92. doi.org/10.21009/bahtera.201.08

Kementerian Pendidikan dan Kebudayaan. (2016a). Asesmen Kompetensi Siswa Indonesia (AKSI)/Indonesia National Assessment Programme (INAP). 1-2. Pusat Penilaian Pendidikan.

Kementerian Pendidikan Dan Kebudayaan. (2016b). Manual pendukung pelaksanaan Gerakan Literasi Sekolah untuk jenjang Sekolah Menengah Pertama. Jakarta: Direktorat Jenderal Pendidikan Dasar Dan Menengah.

Kementerian Pendidikan dan Kebudayaan. (2018). Laporan kajian bahan kebijakan Teknis Literasi Nasional Tahun 2018. Jakarta: Badan Pengembangan dan Pembinaan Bahasa Kemendikbud.

Kementerian Pendidikan dan Kebudayaan. (2019a). Desain Induk Gerakan Literasi Sekolah (2 ${ }^{\text {nd }}$ ed.). Jakarta: Direktorat Jenderal Pendidikan Dasar Dan Menengah Kementerian Pendidikan Dan Kebudayaan.

Kementerian Pendidikan dan Kebudayaan. (2019b). Panduan GLS di SMP ( $2^{\text {nd }}$ ed.). Jakarta: Direktorat Jenderal Pendidikan Dasar Dan Menengah Kementerian Pendidikan Dan Kebudayaan.

Kementerian Pendidikan dan Kebudayaan. (2019c). Indeks aktivitas literasi membaca 34 provinsi. Jakarta: Pusat Penelitian Kebijakan.

Mayuni, I., Leiliyanti, E., Agustina, N., Yulianti, V., Chen, Y., \& Chu, F. I. (2020). School literacy movement and its implications towards students' learning: A comparative case study in Jakarta and Taiwan. International Journal of Advanced Science and Technology, 29(4, Special Issue), 1555-1569. http://sersc.org/journals/index.php/IJAST/article/view/6937

Mayuni, I., Leiliyanti, E., Agustina, N., \& Antoro, B. (2020). The praxis of literacy movement in Indonesian context. International Conference on Humanities, Education and Social Sciences (IC-HEDS) 2019, 897-909. doi.org/10.18502/kss.v4i14.7946

Merga, M.K. (2020). What is the literacy supportive role of the school librarian in the United Kingdom? Journal of Librarianship and Information Science, 53(4)601-614. doi/10.1177/ 0961000620964569

Mokoagow, N., Pongoh, S., \& Watung, S. (2021). Pengaruh program gerakan literasi sekolah dan fasilitas perpustakaan terhadap minat baca siswa di SMA Negeri 1 Tondano. Jurnal Pendidikan Ekonomi, 6(1). https://www.ejournal.fekon-unima.ac.id/index.php/JPE/article/ view/2416

Murti, D.P., \& Winoto, Y. (2018). Hubungan antara kemampuan literasi informasi dengan prestasi belajar siswa SMAN 1 Cibinong Kabupaten Bogor. BIBLIOTIKA/ : Jurnal Kajian Perpustakaan dan Informasi, 2(1), 1-5. doi.org/10.17977/um008v2i12018p001

OECD. (2016). PISA 2015 Results in Focus. https://www.oecd.org/pisa/pisa-2015-results-infocus.pdf 
OECD. (2019). PISA 2018 results: Combined executive summaries. https://www.oecd.org/pisa/ Combined_Executive_Summaries_PISA_2018.pdf

Pilgreen, J.L. (2000). The SSR handbook: How to organize and manage sustained silent reading program. Portsmouth: Boynton/Cook Publishers, Inc.

Ramandanu, F. (2019). Gerakan Literasi Sekolah (GLS) melalui pemanfaatan sudut baca kelas sebagai sarana alternatif penumbuhan minat baca siswa. Mimbar IImu, 24(1), 10-19. doi.org/10.23887/mi.v24i1.17405

Rayantie, R., Hartati, T., \& Rengganis, I. (2019). Penerapan strategi PQRST untuk meningkatkan kemampuan membaca pemahaman siswa kelas V SD. Jurnal Pendidikan Guru Sekolah Dasar, 4(3), 289-297. doi.org/10.17509/jpgsd.v4i3.22934

Sari, M.I., Astuti, H.W., Lubis, I.H., \& Hutagalung, T. (2020). Peningkatan kemampuan membaca pemahaman dengan strategi questioning siswa Kelas VII MTs. Laboratorium UIN-SU. Jurnal Penelitian, Pendidikan dan Pengajaran, 1(2), 48-59. doi.org/10.30596/ jppp.v1i2.5343

Srirahayu, D.P., Kusumaningtiyas, T., \& Harisanty, D. (2021). The role of the school librarian toward the implementation of the School Literacy Movement (Gerakan Literasi Sekolah) in East Java. Library Philosophy and Practice, 2021(2018), 1-15. https:// digitalcommons.unl.edu/cgi/viewcontent.cgi?article=8876\&context=libphilprac

Suyanto, A. (2021). Meningkatkan kemampuan atau kompetensi guru dalam penerapan pendidikan karakter melalui supervisi klinis di SD Negeri Mangunsari Kecamatan Tekung Kabupaten Lumajang. Jurnal Merdeka Mengajar, 2(1), 6-12. https:// www.ejurnalkotamadiun.org/index.php/JMM/article/view/764/683 